\title{
METHODS
}

UDC $57.083 .3+543.9$

doi: https://doi.org/10.15407/ubj89.01.082

\section{VALIDATION OF BIOLOGICAL ACTIVITY TESTING PROCEDURE OF RECOMBINANT HUMAN INTERLEUKIN-7}

\author{
T. N. LUTSENKO ${ }^{1,2}$, M. V. KOVALENKO 3 , O. Yu. GALKIN ${ }^{2}$ \\ ${ }^{1}$ LLC “UA PRO-PHARMA”, Kyiv; \\ ${ }^{2}$ National Technical University of Ukraine "Igor Sikorsky Kyiv Polytechnic Institute”; \\ ${ }^{3}$ Institute of Molecular Biology and Genetics of the National \\ Academy of Sciences of Ukraine, Kyiv; \\ e-mail: tanywalytsenko@gmail.com
}

Validation procedure for method of monitoring the biological activity of recombinant human interleukin-7 has been developed and conducted according to the requirements of national and international recommendations. This method is based on the ability of recombinant human interleukin-7 to induce proliferation of $T$ lymphocytes. It has been shown that to control the biological activity of recombinant human interleukin-7 peripheral blood mononuclear cells (PBMCs) derived from blood or cell lines can be used. Validation characteristics that should be determined depend on the method, type of product or object test/measurement and biological test systems used in research. The validation procedure for the method of control of biological activity of recombinant human interleukin-7 in peripheral blood mononuclear cells showed satisfactory results on all parameters tested such as specificity, accuracy, precision and linearity.

Ke y word s: recombinant human interleukin-7 (rhIL-7), biological activity, peripheral blood mononuclear cells (PBMCs), validation.

$\mathrm{O}$ ne of the most essential steps of development of medicinal products (MPs) is preclinical studies - a complex of investigation procedures and operations for the study of toxicity and specific activity of potential bioactive substances. Appropriate conduct of these studies has to guarantee safety and high therapeutic efficacy of the developed MPs. The main instruments of preclinical studies are various pharmacological methods involving the use of several analytical measurements and tests on various biological objects. That is why these methods may be classified as bioanalytical.

Validation is a procedure which gives a high degree of assurance that a particular process, method, or system consistently lead to results that meet predetermined acceptance criteria. Validation of analytical method represents experimental evidences that the method is suitable for its intended purpose [1]. An important issue of validation of bioanalytical procedures is the absence of precise methodic guidelines on selection of the necessary parameters and performance methods. Besides, the use of pharmacopeias and/or reference samples (as a basic element of validation of chemical analytical procedures) is mostly impossible during assessment of biological samples due to their absence. Analytical procedures' suitability evaluation is one of the most essential elements of quality assurance system of pharmaceutical and biotechnological products [2].

The goal of this study was validation of bioanalytical procedure for control of biological activity of recombinant human interleukin-7 (rhIL-7) in accordance with requirements of national and international guidelines.

\section{Materials and Methods}

Isolation of human peripheral blood mononuclear cells (PBMCs) and their stimulation. Blood 
was obtained from verified donors (under Article 16 of the Law of Ukraine "On donor service of blood and blood components") using heparin (10 U/ $\mathrm{ml}$ of blood was used) or EDTA as anticoagulants. The blood volume was $14 \mathrm{ml}$. Blood separation was performed in a centrifuge with bucket rotor (Liston 2204 Classic) for $30 \mathrm{~min}$ at $1500 \mathrm{rpm}$ at room temperature using density gradient Histopaque 1077 (Sigma, USA). PBMCs were collected with a sterile pipette and washed twice with $10 \mathrm{ml}$ of rinsing medium (RPMI-1640, Biowest, USA, containing $2 \%$ fetal calf serum) by centrifugation for $10 \mathrm{~min}$ at $1000 \mathrm{rpm}$ at room temperature. Then the cells were resuspended in $4 \mathrm{ml}$ of the culture medium (RPMI with $10 \%$ fetal calf serum, $10 \mu \mathrm{g} / \mathrm{ml}$ of phytohemagglutinin (PHA) (Sigma, USA, L - 8754) and $50 \mathrm{mM}$ mercaptoethanol), and the number of viable cells was calculated upon staining with $0.4 \%$ trypan blue in Goryaev counting chamber. The cells were diluted to the concentration of (1-4) $\times 10^{6}$ cells $/ \mathrm{ml}$ with the culture medium and cultivated in T45 flasks $(10 \mathrm{ml} /$ flask) for 5 days at $37{ }^{\circ} \mathrm{C}$ in a $5 \% \mathrm{CO}_{2}$ atmosphere. After PHA stimulation, the cell suspension was centrifuged at $1000 \mathrm{rpm}$ for $10 \mathrm{~min}$ and the cells were washed once as described earlier. Then the cells were again resuspended in 3-5 $\mathrm{ml}$ of culture medium, and the number of viable cells was calculated upon staining with $0.4 \%$ trypan blue in Goryaev counting chamber. The cells were diluted to the concentration of $2 \times 10^{6}$ cells $/ \mathrm{ml}$ and added into $96-w e l l$ plates, introducing $50 \mu \mathrm{l}$ into each well.

Biological activity control procedure. Reference sample solutions were prepared as follows: rhIL-7 (PeproTech, USA) was used as the reference sample; a solution No 1 was prepared by dilution of the reference sample with phosphate buffer $\mathrm{pH} 7.4$ and addition of $0.1 \%$ BSA to the concentration of $1 \mathrm{ng} / \mu 1$. The following dilutions (ng/ml): $0.125,0.25,0.5,1.0$, 2.0, 3.0, 4.0, 5.0, 6.0 were prepared from the solution No 1 with PBMCs culture medium.

Used in test sample rhIL-7 was obtained by recombinant DNA technology in E. coli cells and purified using stepwise chromatographic purification at LLC "Universal Agency PRO-PHARMA" [3]. Test sample solutions were prepared as follows: first a solution No 1 was prepared by dilutions in phosphate buffer $\mathrm{pH} 7.4$ from the obtained sample with addition of $0.1 \%$ BSA to the rhIL-7 concentration $1 \mathrm{ng} / \mu \mathrm{l}$. The following dilutions $(\mathrm{ng} / \mathrm{ml})$ : $0.25,0.5,2.0,5.0,10.0$, 20.0, 30.0, 40.0, 50.0 were prepared from the solution No 1 in PBMCs culture medium.
The obtained dilutions of a reference sample and test sample were transfered into wells of PBMC-containing plate in the volume of $50 \mu \mathrm{l}$ in triplicate and incubated for 4 days at $37{ }^{\circ} \mathrm{C}$ in an incubator with $5 \% \mathrm{CO}_{2}$. After that, $15 \mu 1$ of methylthiazole tetrazolium bromide (MTT) solution $(5 \mathrm{mg}$ / $\mathrm{ml}$ ) was added into each well and incubated for $4 \mathrm{~h}$ at $37{ }^{\circ} \mathrm{C}$ in the incubator with $5 \% \mathrm{CO}_{2}$. After that, $200 \mu 1$ of DMSO was added into each well to dissolve formazan crystals. Optical density (OD) was measured at $570 \mathrm{~nm}$ (spectrophotometer 6320D VIS, Jenway). The relation plot of optical density against IL-7 concentration logarithm was generated (the plot had the appearance of sigmoid curve). The effective dose $\left(E D_{50}\right)$ was calculated from linear part of the plot and represented $50 \%$ proliferative response of the maximum proliferative response obtained in the linear part of the plot. For $\mathrm{ED}_{50}$ calculation, the sigmoid curve data obtained were approximated using statistical software packages [4].

Mathematical (statistical) methods. The optimized method of biological activity control was verified in accordance with procedures described in guidelines of the International Conference on Harmonization of Technical Requirements for Registration of Pharmaceuticals for Human Use (ICH), Validation of Analytical Procedures Q2 (R1) [5], as well as Microsoft Excel software. The following validation parameters were reviewed: specificity, linearity and range, accuracy, precision, and robustness $[1,6,7]$.

All calculations were performed in "normalized" coordinates. This allowed formulating unified criteria related with content tolerance limits only, but independent of the specific properties of individual values. Normalized coordinates were established as follows:

$$
\begin{aligned}
& X_{i}=\frac{C_{i}}{C_{s t}} \times 100 \% \\
& Y_{i}=\frac{A_{i}}{A_{s t}} \times 100 \%,
\end{aligned}
$$

where $C_{i}$ - test substance concentration in i-th solution (or sample), $C_{s t}$ - concentration of the same substance in the reference solution, $A_{i}$ - analytical signal of the substance tested for $i$-th test solution, $A_{s t}$ - analytical signal of the same substance for the reference solution.

Subsequently, all calculations and criteria were performed for normalized values $X_{i}$ and $Y_{i}$. 
Linear relation was calculated using the least square method

$$
\begin{aligned}
& \left(A_{i} / A_{\mathrm{s}}\right) 100=b\left(\mathrm{C}_{\mathrm{i}} / \mathrm{C}_{\mathrm{s}}\right) 100+a, \\
& Y_{i}=b X_{i}+a,
\end{aligned}
$$

where $a-$ absolute term for the calculated regression line ( $y$ intercept); $b$ - slope for the calculated regression line.

Concentrations tested during linearity study were characterized by standard deviation.

$\mathrm{RSD}_{\mathrm{y}}(\%)$, calculated using the formula:

$$
R S D_{y}=\sqrt{\frac{\sum\left(C_{1}-\bar{C}\right)^{2}}{\bar{C}^{2} \times(g-1)}} \times 100 \%,
$$

where $C_{i}-i$-th solution concentration; $C$ - mean concentration of solutions; $g$ - sample volume (the number of points on a line) [6].

\section{Results and Discussion}

Comparative characteristics of assessment methods of human interleukin-7 biological activity. A set of validation characteristics to be determined is dependent on the method, product type or test/ measurement object, as well as biological test systems the study will be conducted in. Typical validation characteristics include: accuracy, precision (re- peatability, intermediate precision, reproducibility), specificity, limit of detection, linearity, and range. The set of characteristics and methodological approaches to their determination are dependent on each specific procedure, but the presence/absence of each characteristic has to be justified.

Test method of control of the rhIL-7 biological activity is based on its ability to cause T-lymphocyte proliferation. Human peripheral blood mononuclear cells (PBMCs) obtained from donor blood or cell lines may be used for testing of rhIL-7 biological activity. At present, there are several interleukin7-dependent cell lines in the world, which may be used for testing of rhIL-7 biological activity: $1 \mathrm{xN} / 2 \mathrm{~b}$ (stromal cell line), 2E8 (mouse B-lymphocytes), D1 (knockout mice thymocytes), DW34 (pre-B-cells), PB-1 (pre-B-cells), Pno (T-cells). Table 1 contains brief comparative characterization of cell lines which may be used for testing of biological activity of rhIL-7 $[3,8,9]$.

Cells used for control were pre-stimulated with PHA. If finite cell lines are used, cellular growth always has to be maintained in the presence of human interleukin-7 reference sample with known activity, thus we have selected PBMCs for biological activity testing from the viewpoint of technical-economical

Table 1. Brief characterization of interleukin-7 dependent cell lines

\begin{tabular}{|l|l|l|l|}
\hline \multicolumn{1}{|c|}{$\begin{array}{c}\text { Cell } \\
\text { line }\end{array}$} & \multicolumn{1}{|c|}{ Cell types } & \multicolumn{1}{|c|}{$\begin{array}{c}\text { Interleukin-7 } \\
\text { dependence }\end{array}$} & \multicolumn{1}{|c|}{ Interleukin-7 test method } \\
\hline 1xN/2b & Mouse stromal cells & $\begin{array}{l}\text { Growth and } \\
\text { viability absolute } \\
\text { dependence on IL-7 }\end{array}$ & $\begin{array}{l}\text { Method using tritium-labeled } \\
\text { thymidine, MTT-method, as well as } \\
\text { an alternative PCR method for the } \\
\text { measurement of number of cytokines }\end{array}$ \\
\hline 2E8 & Mouse bone marrow cells & $\begin{array}{l}\text { Growth and survival } \\
\text { dependence on IL-7 }\end{array}$ & $\begin{array}{l}\text { Method using tritium-labeled } \\
\text { thymidine, MTT-method }\end{array}$ \\
\hline D1 & $\begin{array}{l}\text { Knockout mice } \\
\text { thymocytes }\end{array}$ & $\begin{array}{l}\text { Partial dependence } \\
\text { on IL-7 }\end{array}$ & $\begin{array}{l}\text { Method using tritium-labeled } \\
\text { thymidine, MTT-method }\end{array}$ \\
\hline DW34 & Mouse bone marrow cells & $\begin{array}{l}\text { Total dependence } \\
\text { on IL-7 }\end{array}$ & $\begin{array}{l}\text { Method using tritium-labeled } \\
\text { thymidine, MTT-method, as well as } \\
\text { an alternative PCR method for the } \\
\text { measurement of number of cytokines }\end{array}$ \\
\hline PB-1 & Mouse bone marrow cells & $\begin{array}{l}\text { Total dependence } \\
\text { on IL-7 }\end{array}$ & $\begin{array}{l}\text { Method using tritium-labeled } \\
\text { thymidine, MTT-method }\end{array}$ \\
\hline Pno & $\begin{array}{l}\text { Peripheral blood } \\
\text { lymphocytes of } \\
\text { humans with skin } \\
\text { T-cellular lymphoma }\end{array}$ & $\begin{array}{l}\text { Partial dependence } \\
\text { on IL-7 }\end{array}$ & $\begin{array}{l}\text { Method using tritium-labeled } \\
\text { thymidine, MTT-method }\end{array}$ \\
\hline
\end{tabular}


parameters. Proliferation assessment may be performed by two methods using either 3-(4,5-dimethylthiazole-2-yl)-2,5-biphenyl tetrazolium bromide (MTT test), or tritium-labeled thymidine (thymidine test) $[3,10]$. Use of labeled thymidine for detection has several disadvantages related with the need in handling radioactive material, as well as its disposal, thus, we have given preference to MTT test for biological activity control.

Method specificity assessment. Specificity of the method is its ability to assess biological activity of a particular test substance in the presence of other components which may be found in a sample. As biological activity testing is one of identification methods used for control of active pharmaceutical ingredients and finished medicinal products based on rhIL-7, specificity is the proof of the fact that the test substance is actually identified.

We have suggested testing the specificity of our rhIL-7 in test sample versus rhIL-7 (Peprotech, USA, Cat.N. 200-07) in reference sample on human PBMCs. In accordance with requirements of national and international recommendations, RSD may not exceed $2 \%[1,8]$.

Fig. 1 shows the results of specificity testing of the method - proliferation of human peripheral blood cells at increasing rhIL-7 concentration. The obtained $\mathrm{ED}_{50}$ values for the test and the reference samples were 2 and $5 \mathrm{ng} / \mathrm{ml}$, respectively. This gave us grounds to believe that the test sample has the appropriate biological activity. It was lower than that observed in the reference sample. Nevertheless, these results are related solely with poorly optimized test sample purification conditions. Thus, the obtained results are indicative of the fact that this method is specific with regard to rhIL-7.

Assessment of range $(R)$ and linearity. The following dilutions of the obtained rhIL-7 in PBMCs culture medium: (ng/ml) 0.125, 0.25, 0.5, 1.0, 2.0, 3.0, 4.0, 5.0, 6.0 were used for the testing of the said validation characteristics. Control of each dilution was performed in triplicate.

Table 1 and Fig. 2 show the results of optical density dependence on rhIL-7 concentration. Thus, according to the obtained results, it can be concluded that the admissible minimum range for recombinant human interleukin-7 testing with this method is $0.125 \mathrm{ng} / \mathrm{ml}$.

The data obtained were used to calculate linear regression equations listed in Table 2 . The test linearity was assessed by analysis of the obtained equations. Slope coefficient of linear regression plot was within the limits of 1.011-1.028, which is an acceptable result for quantitative bioanalytical procedure. Correlation coefficients $(r)$ between experimental and theoretical OD values were compared against the critical value for different significance levels [6]. The obtained results (Table 2) are indicative of acceptable level of conformity between experimental data and OD results calculated using linear regression equation for test samples of recombinant human interleukin-7.

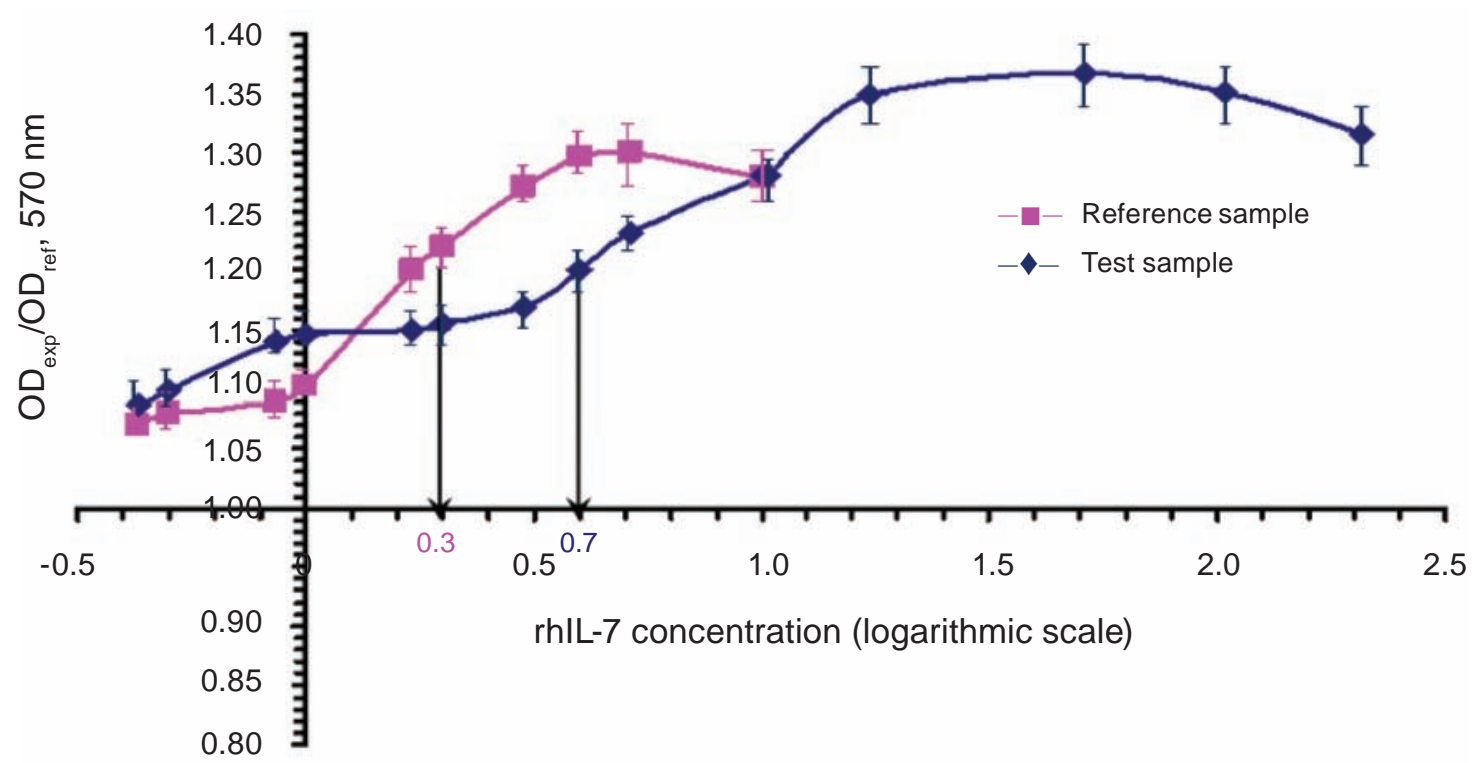

Fig. 1. Specificity testing of the method-proliferation of human peripheral blood cells at increasing rhIL-7 concentration $(M \pm m ; n=3 ; P<0.05)$ 
Ta ble 2. Results of rhIL-7 biological activity and linearity assessment

\begin{tabular}{c|ccc|c|c}
\hline $\begin{array}{c}\text { Solution } \\
\text { dilution, } \\
\mathrm{ng} / \mathrm{ml}\end{array}$ & \multicolumn{3}{|c}{ Optical density (OD) } & $\begin{array}{c}\text { Linear regression } \\
\text { equation }\end{array}$ & $\begin{array}{c}\text { Correlation coefficient } r \text { and its } \\
\text { significance level }\end{array}$ \\
\hline 0.125 & 0.037 & 0.036 & 0.036 & $y=1.021 x-0.125$ & $0.995(P \leq 0.01)$ \\
0.250 & 0.037 & 0.038 & 0.004 & $y=1.011 x-0.142$ & $0.998(P \leq 0.02)$ \\
0.50 & 0.512 & 0.517 & 0.516 & $y=1.016 x-0.124$ & $0.996(P \leq 0.02)$ \\
1.00 & 0.588 & 0.589 & 0.577 & $y=1.023 x-0.128$ & $0.994(P \leq 0.04)$ \\
2.00 & 0.599 & 0.586 & 0.596 & $y=1.028 x-0.111$ & $0.997(P \leq 0.02)$ \\
3.00 & 0.601 & 0.599 & 0.603 & $y=1.026 x-0.118$ & $0.999(P \leq 0.01)$ \\
4.00 & 0.612 & 0.613 & 0.611 & $y=1.024 x-0.101$ & $0.995(P \leq 0.01)$ \\
5.00 & 0.631 & 0.629 & 0.630 & $y=1.032 x-0.106$ & $0.996(P \leq 0.02)$ \\
6.00 & 0.631 & 0.632 & 0.631 & $y=1.015 x-0.114$ & $0.995(P \leq 0.01)$ \\
\hline
\end{tabular}

Accuracy and precision assessment. It is well known that precision may be reviewed at different levels, in particular: repeatability (intra assay variation) characterizes variations in test procedures in the same conditions within a short time span; intermediate precision (inter assay variation) takes into account intralaboratory variations; reproducibility characterizes the proximity degree of results at interlaboratory experiment [11-13].

In our study, the testing of accuracy and repeatability expressed through coefficient of varia- tion $\mathrm{CV}_{\text {intra }}$ were carried out simultaneously. As biological activity test method is quantitative, the measurements were performed by testing 9 dilutions, concentrations of which were uniformly distributed within the tested range of this procedure ng/ ml: $0.125,0.25,0.5,1,2,3,4,5,6$. Testing of each dilution was performed in triplicate. Intermediate precision $\mathrm{CV}_{\text {inter }}$ testing was performed by conducting the experiment 3 times by different laboratory technicians on different PBMCs samples. RSD percentage for the studies was established as less than

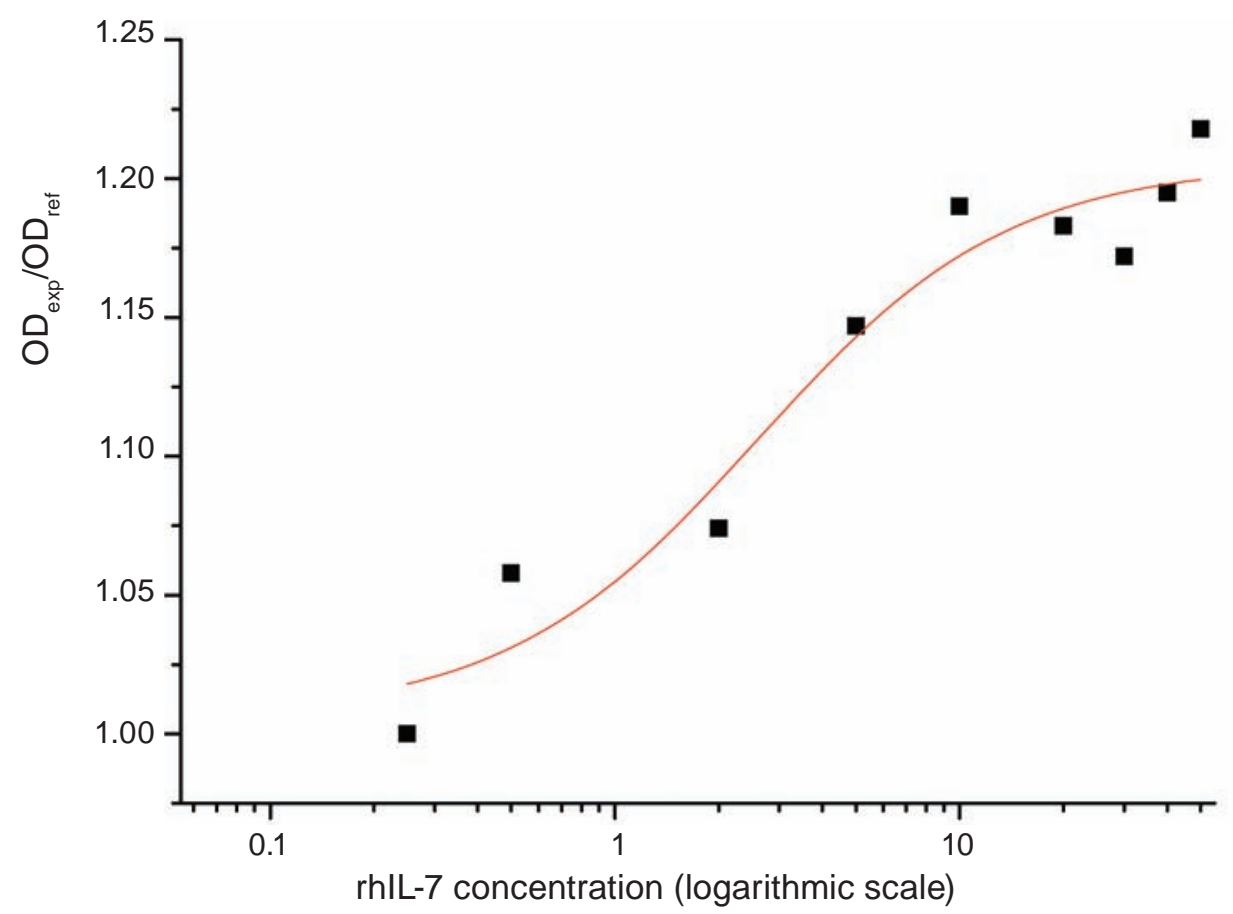

Fig. 2. Establishment of linear relation between optical density and rhIL-7 concentration 

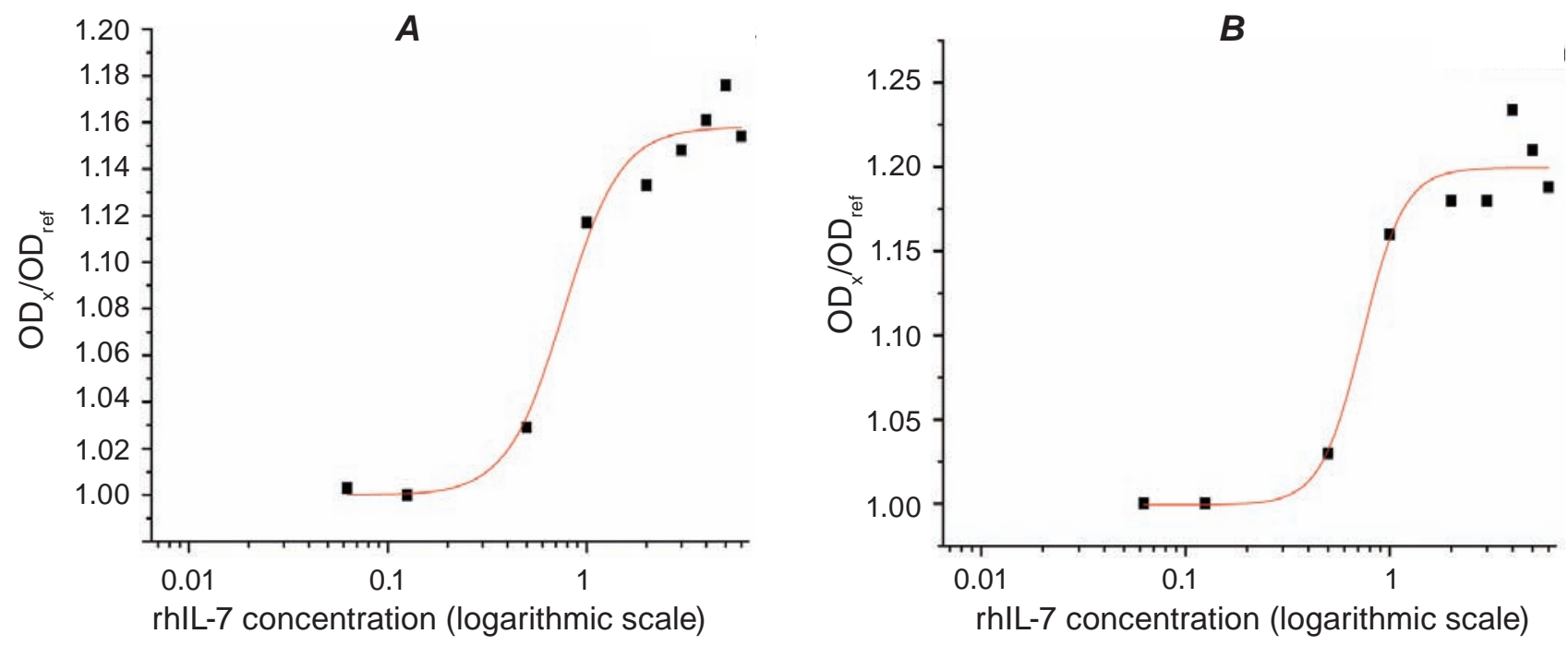

Fig. 3. PBMCs proliferation. A: reference sample - IL-7: 0.0625, 0.125, 0.5, 1, 2, 3, 4, 5 and 6 ng, proliferation PBMCs obtained from Donor 1. B: reference sample - IL-7: 0.0625, 0.125, 0.5, 1, 2, 3, 4, 5 and 6 ng proliferation PBMCs obtained from Donor 2. Reference sample $E D_{50}$ calculation was performed using statistical

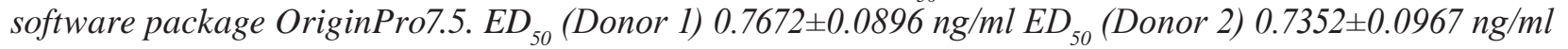

Ta b le 3. Repeatability and intermediate precision results for biological activity testing of recombinant human interleukin-7

\begin{tabular}{|c|c|c|c|c|}
\hline Plate & $\begin{array}{l}\text { Mean } \\
\text { OD for } \\
\text { a plate }\end{array}$ & $\begin{array}{c}\text { Mean OD } \\
\text { for all } \\
\text { plates }\end{array}$ & $\begin{array}{l}\text { Standard } \\
\text { deviation }\end{array}$ & $\mathrm{CV}_{\text {intra }}$ \\
\hline \multicolumn{5}{|c|}{ For reference sample } \\
\hline 1 & 0.532 & \multirow{4}{*}{0.534} & \multirow{4}{*}{0.034} & \multirow{4}{*}{$6.3 \%$} \\
\hline 2 & 0.533 & & & \\
\hline 3 & 0.535 & & & \\
\hline 4 & 0.534 & & & \\
\hline \multicolumn{5}{|c|}{ For test sample } \\
\hline 1 & 0.540 & \multirow{4}{*}{0.542} & \multirow{4}{*}{0.020} & \multirow{4}{*}{$6.9 \%$} \\
\hline 2 & 0.541 & & & \\
\hline 3 & 0.544 & & & \\
\hline 4 & 0.544 & & & \\
\hline
\end{tabular}

$2.0 \%$, which is a very good parameter for bioanalytical procedure accuracy assessment. For precision assessment, this analysis was conducted in parallel on PBMCs obtained from two different donors.

Results of the relevant experiments are shown in Tables 3 and 4 and in Fig. 3. Repeatability mean values $\left(\mathrm{CV}_{\text {intra }}\right)$ of biological activity testing were $6.3 \%$ for the reference sample and $6.9 \%$ for the test sample. Intermediate precision of the test, where PB-
Ta b le 4. Intermediate precision measurement results for biological activity testing of recombinant human interleukin-7

\begin{tabular}{|c|c|c|c|c|}
\hline Exper. & $\begin{array}{c}\text { Mean } \\
\text { OD for } \\
\text { a test }\end{array}$ & $\begin{array}{l}\text { Standard } \\
\text { deviation }\end{array}$ & $\mathrm{CV}_{\text {intra }}$ & $\begin{array}{l}\text { Mean } \\
\mathrm{CV}_{\text {intra }}\end{array}$ \\
\hline \multicolumn{5}{|c|}{ For PBMCs obtained from the first donor } \\
\hline 1 & 0.645 & 0.046 & $5.7 \%$ & \multirow{3}{*}{$5.2 \%$} \\
\hline 2 & 0.640 & 0.032 & $3.5 \%$ & \\
\hline 3 & 0.635 & 0.062 & $6.4 \%$ & \\
\hline \multicolumn{5}{|c|}{ For PBMCs obtained from the second donor } \\
\hline 1 & 0.651 & 0.048 & $7.3 \%$ & \multirow{3}{*}{$7.5 \%$} \\
\hline 2 & 0.657 & 0.042 & $6.4 \%$ & \\
\hline 3 & 0.656 & 0.058 & $8.8 \%$ & \\
\hline
\end{tabular}

MCs from two different donors were used, varied within the range of $3.5 \%$ to $8.8 \%\left(\mathrm{CV}_{\text {inter }}\right.$ mean value was $6.35 \%$ ). According to various recommendations, different $\mathrm{CV}_{\text {intra }}$ and $\mathrm{CV}_{\text {inter }}$ values are acceptable: some authors recommend regulating these values at the level $\mathrm{CV} \leq 10 \%$, and others believe the results are acceptable if these values do not exceed the limit of $20 \%$. Test precision results, we have obtained, are indicative of their suitability for biological activity testing of recombinant human interleukin-7 in donor PBMCs. 
The suggested method for biological activity testing of rhIL-7 in human PBMCs was validated for confirmation of its biological activity quantitative characteristic. Validation has confirmed that this method showed the reliable data for all tested parameters such as specificity, accuracy, precision and linearity. The method linearity was satisfactory. Repeatability of test result was within the range of 6.3 to $6.9 \%$, and intermediate precision was from 3.5 to $8.8 \%$, which is an acceptable result $(\leq 10 \%)$. The bioanalytical assay for biological activity testing of rhIL-7 in donor PBMC has been recognized as validated with satisfactory results.

\section{ВАЛІДАЦІЯ МЕТОДИКИ ВИЗНАЧЕННЯ БІОЛОГІЧНОЇ АКТИВНОСТІ РЕКОМБІНАНТНОГО ІНТЕРЛЕЙКІНУ-7 ЛЮДИНИ}

\author{
Т. М. Луценкко, ${ }^{1,2}$ М. В. Коваленко \\ О. Ю. Галкін ${ }^{2}$
}

${ }^{1}$ ТОВ Універсальне агентство «Про-фарма», Київ; ${ }^{2}$ Національний технічний університет України «Київський політехнічний інститут імені Ігоря Сікорського»; ${ }^{3}$ Інститут молекулярної біології і генетики НАН України, Київ; e-mail: tanywalytsenko@gmail.com

Розроблено та проведено процедуру валідації методики контролю біологічної активності рекомбінантного інтерлейкіну-7 людини згідно 3 вимогами національних та міжнародних рекомендацій. Розроблена методика базується на здатності рекомбінантного інтерлейкіну-7 людини спричинювати проліферацію Т-лімфоцитів. Показано, що для контролю біологічної активності рекомбінантного інтерлейкіну-7 людини можливе використання мононуклеарних клітин периферичної крові (МКПК) людини, які отримують із донорської крові або перевиваємих клітинних ліній. Валідаційні характеристики, які необхідно визначати, залежать від методу, типу продукції чи об'єкту випробування/вимірювання, а також від біологічних тест-систем, що застосовують під час дослідження. Процедура валідації методики контролю біологічної активності інтерлейкіну-7 на мононуклеарних клітинах периферичної крові людини показала задовільні результати за всіма параметрами тестування, таких як специфічність, правильність, прецизійність та лінійність.

К л юч о в і слов а: рекомбінантний інтерлейкін-7 людини, біологічна активність, монононуклеарні клітини периферичної крові (МКПК), валідація.

\section{ВАЛИДАЦИЯ МЕТОДИКИ ОПРЕДЕЛЕНИЯ БИОЛОГИЧЕСКОЙ АКТИВНОСТИ РЕКОМБИНАНТНОГО ИНТЕРЛЕЙКИНА-7 ЧЕЛОВЕКА}

\author{
Т. Н. Луценко ${ }^{1,2}$, М. В. Коваленко \\ А. Ю. Галкин ${ }^{2}$
}

${ }^{1}$ ООО Универсальное агентство «Про-фарма», Киев; ${ }^{2}$ Национальный технический университет Украины «Киевский политехнический институт имени Ігоря Сикорского»; ${ }^{3}$ Институт молекулярной биологии и генетики НАН Украины, Киев; e-mail: tanywalytsenko@gmail.com

Разработана и проведена процедура валидации методики контроля биологической активности рекомбинантного интерлейкина-7 человека согласно с требованиями национальных и международных рекомендаций. Разработанная методика основана на способности рекомбинантного интерлейкина-7 человека вызывать пролиферацию Т-лимфоцитов. Показано, что для контроля биологической активности рекомбинантного интерлейкина-7 человека можно использовать мононуклеарные клетки периферической крови (МКПК) человека, полученные из донорской крови или перевиваемых клеточных линий. Валидационные характеристики, которые необходимо определить, зависят от метода, типа продукции или объекта испытания/измерения, а также от биологических тест-систем, используемых при исследовании. Процедура валидации методики контроля биологической активности интерлейкина-7 на мононуклеарных клетках периферической крови человека показала удовлетворительные результаты по всем параметрам тестирования, таким как специфичность, правильность, прецизионность и линейность.

Кл ю че в ы е с лов в: рекомбинантный интерлейкин-7 человека, биологическая активность, монононуклеарные клетки периферической крови (МКПК), валидация. 


\section{References}

1. State Pharmacopoeia of Ukraine. First Edition. Amendment 2. Ed. Hryzoduba O.I. Kh.: RIREH, 2008. 617 p. (In Ukrainian).

2. RMG 61-2010. State system for ensuring the uniformity of measurements. Indicators of precision, accuracy, precision of the quantitative chemical analysis techniques. Evaluation methods. Instead RMG 61-2003; 09/01/2012 of administering a date. M.: Standartynform, 2012. 60 p. (In Russian).

3. Lutsenko TN, Galkin AY. Substantion of biotechnological approaches of producing interleukin-7 recombinant human. Proc Belarus State Technol Univ. 2015; 177: 188-197. (In Russian).

4. Yokota T, Otsuka T, Mosmann T, Banchereau J, DeFrance T, Blanchard D, De Vries JE, Lee F, Arai $\mathrm{K}$. Isolation and characterization of a human interleukin cDNA clone, homologous to mouse B-cell stimulatory factor 1 , that expresses B-cell- and T-cell-stimulating activities. Proc Natl Acad Sci USA. 1986; 83(16): 5894-5898.

5. Note for guidance on validation of analytical procedures: text and metodology (CPMP/ ICH/381/95). London: European Medicines Agency, 1995. $15 \mathrm{p}$.

6. Urbach VY. Mathematical statistics for biologists and physicians. M.: Publishing house of the Academy of Sciences of the USSR, 1963. 321 p. (In Russian).

7. Guide for the pharmaceutical industry/of methodical recommendations. M.: 2000 Sport and Culture Publisher, 2007. 192 p. (In Russian).

8. Armitage RJ, Namen AE, Sassenfeld HM, Grabstein KH. Regulation of human $\mathrm{T}$ cell proliferation by IL-7. J Immunol. 1990; 144(3): 938-941.
9. Biotechnological bases of creation tools serological diagnosis of infec-tious and noninfectious diseases: Monograph. OYu Galkin, VP Shyrobokov, AA Grigorenko, OM Dugan, TM Lutsenko, AG Komar; Ed. VP Shyrobokov. K.: NTU "KPI"; 2015. 204 p. (In Ukrainian).

10. van de Loosdrecht AA, Beelen RH, Ossenkoppele GJ, Broekhoven MG, Langenhuijsen MM. A tetrazolium-based colorimetric MTT assay to quantitate human monocyte mediated cytotoxicity against leukemic cells from cell lines and patients with acute myeloid leukemia. J Immunol Methods. 1994; 174(1-2): 311-320.

11. Galkin $\mathrm{OYu}$, Gorshunov $\mathrm{Y}$, Besarab OB. Bioanalytical validation of enzyme immunoassay for the qualitative (semiquantitative) determination of IgA class antibodies to Chlamydia trachomatis. Sci Notes Taurida Nat VI Vernadsky Univ. Series Biology and Chemistry. 2014; 27(66)(3): 14-25. (In Ukrainian).

12. Galkin OYu, Besarab OB, Gorshunov YuV, Dugan OM. Bioanalytical validation of immunoenzymatic test-kit for quantitative determination of total human immunoglobulin E. Sci Notes Ternopil Volodymyr Hnatiuk Nat Pedag Univ. Series Biology. 2014; 4: 133-141. (In Ukrainian).

13. Galkin AYu, Komar AG, Grigorenko AA. Bioanalytical standardizing for serological diagnostic medical devices. Biotechnologia Acta. 2015; 8(2): 112-119. (In Ukrainian).

Received 31.10.2016 